\title{
Summer Scenes and Flowers: The Beginnings of the \\ New Zealand Christmas Card, 1880-1882
}

Peter Gilderdale

Keywords: \#Christmas traditions \#card sending \#New Zealand identity \#cultural colonisation \#photography

In October 1883, just as New Zealanders began the annual ritual of buying seasonal tokens of esteem to post overseas, Dunedin's Evening Star, quoting local photographers the Burton Brothers, posed a question that had exercised immigrants for some years. "Does it not seem folly," the paper asked "to send back to the Old Country Christmas cards which were manufactured there and exported hither?" This was a rhetorical question and the Evening Star went on to respond that "a few years since we should have replied 'No'; but in view of the experiences of the last two years we say most decidedly, 'Yes, it is folly."' The newspaper, clearly, saw the period of 1881 and 1882 as pivotal in the establishment of a small but important industry, the New Zealand Christmas card business. ${ }^{2}$ My paper examines why these years are significant and what lies behind the debate, identifying a number of early cards and documenting the accompanying developments, primarily via the lens of newspaper advertising. The 1880 s Christmas card may not have been an industry on the scale of lamb, but what it lacked in bulk it made up for in symbolism, providing a discrete window into the web of entangled emotional, commercial and design imperatives that attended the way immigrants imagined and constructed this important cultural celebration. 
For European immigrants to New Zealand, now as well as then, the move to the other side of the world has an unwelcome side-effect. December 25th falls squarely in the middle of summer. As nineteenth century colonists discovered, regardless of how desirable sun and heat might ordinarily be, the strangeness of southern hemisphere Christmas celebrations foregrounded any lurking sense of dislocation. ${ }^{3}$ According to Alison Clarke, who has particularly focused on New

Zealand Christmas traditions, the transition from a winter to a summer celebration was deeply challenging to settlers' expectations. ${ }^{4}$ Their normal response to such a challenge would have been to reshape it into a form more akin to what they left behind. ${ }^{5}$ The seasons obdurately resisted such a process, but customs were more amenable. Practices like Christmas card exchange allowed settlers a choice about whether to import or redefine traditions. As Clarke notes, card sending pitted nostalgia for deeply felt English traditions against nascent local pride. ${ }^{6}$

Yet the 'traditional' English Christmas, whose enforced absence unsettled the colonists of the 1870 s and 80 s, was a more recent cultural construct than perhaps they realised, and it is necessary to understand something of its background before contextualising New Zealand practice. English Christmas customs had, in fact, altered considerably over the preceding forty years in response to processes of urbanisation and industrialisation. ${ }^{7}$ Originally a community-based, boisterous celebration aligned to the rhythm of the agricultural year, Christmas increasingly gave way to a more privatised celebration, centred on the middle class family, and framed as more of a patriotic, social and commercial celebration than a religious one. ${ }^{8}$

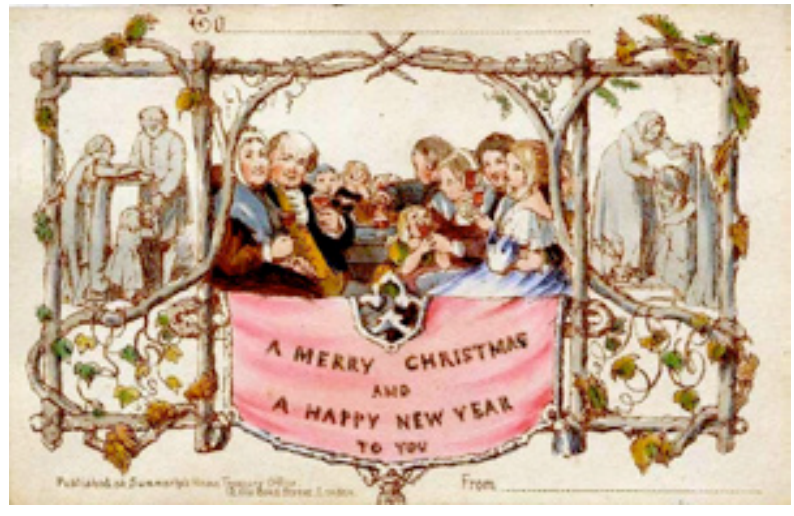

Figure 1: John Callcott Horsley (artist) \& Henry Cole (publisher - under the name Felix Summerly), The Earliest Commercial British Christmas card, 1843 hand coloured engraving, $12.7 \times 7.62 \mathrm{~mm}$ Courtesy of Wikimedia Commons. This card sold for a shilling. Although now widely feted, at the time it was not a success.
This newly reframed Christmas provides the context within which the British Christmas card gradually evolved. The imagery in Henry Cole's first commercial Christmas card from 1843 sums up the revitalised conception of Christmas, with its convivial family gathering, flanked by yuletide acts of charity (Figure 1). Yet, while Christmas annuals and other seasonal publications flourished after the $1840 \mathrm{~s}$ reinforcing the emergent secular and nationalist themes of the English middle-class Christmas, the initial Victorian formulation of Christmas customs did not include Christmas card exchange. ${ }^{9}$ Though there were precedents for associating cards with Christmas, and Valentine cards were already wildly popular, the Cole/Horsley card singularly failed to spawn an industry. ${ }^{10}$ Sporadic, small-scale attempts occurred through the 1840 s and 50 s, primarily with similarly convivial imagery, but when, twenty years later, the genre began to have marketplace success, the imagery had consolidated around northern hemisphere seasonal references such as "robins perched on snow-laden trees."1

In late 1861, at exactly the same time that commercial Christmas card production was establishing itself in Britain, Auckland bookseller and stationer George Chapman advertised "Christmas Note Paper and Christmas Cards of Good Wishes," heralding a flurry of interest in imported Christmas cards over the next year among New Zealand retailers. ${ }^{12}$ After 1862 , however, they disappeared from newspaper adverts for the rest of the decade, reappearing in 1870 . Although doubtless sold and used during this early period, their absence in newspaper adverts suggests that they commanded limited cultural capital. A graph showing card sales (Figure 2) shows that even after 1870 their progress towards becoming a staple of $\mathrm{New}$ Zealand Christmas celebrations was relatively slow. 1876 marked the first noticeable increase, with cards advertised widely outside the main centres for the first time. The New Zealand Herald that year used the appearance of Christmas cards in booksellers' windows as an augury of the approaching season, an indication of their increasing cultural significance..$^{13}$ Yet this appreciation was not universal. Alison Clarke notes that holiday traditions varied amongst different settler communities, and Christmas was not celebrated as a religious holiday by Presbyterians. ${ }^{14}$ Hence it is not surprising to find the Otago Daily Times still having to educate its predominantly Scottish readers (who were more familiar with New Year than Christmas traditions) on card usage, advising that "in the Old Country [Christmas cards] are exchanged between friends at Yule-tide."'s 
Two factors, in particular, help clarify these findings. Until 1870, Christmas was primarily celebrated as a social event, but Mark Connelly argues that this date was pivotal in the rise of commercialisation and the institution of Christmas shopping ${ }^{16}$ In tandem with this trend, the dates 1870 and 1876 correspond with key events in postal legislation. 1870, when card advertisements reappeared in New Zealand newspapers, was the year the postcard was introduced in Britain, and unsealed letters were able to travel domestically at the same reduced rate..$^{17}$ This provided the catalyst for increased Christmas card exchange in Britain, since people could now send printed cards cheaply to their friends and relations in other parts of the country. This trend was evidently noted in New Zealand, but the marked rise in card advertising after 1876 coincides with the introduction of postcards here that year. ${ }^{18}$ Cheaper postcard rates only applied nationally, however, and cards sent internationally still had to be sent at the expensive sixpenny letter rate. These rates applied throughout the period, and would have acted as a disincentive to international card sending. Consequently the pattern of card advertising during the 1870 s was, predictably, targeted solely to the local market, with card adverts first appearing in late November and December. ${ }^{19}$

Number of Christmas Card Mentions in NZ Newspaper advertising, 1870-90

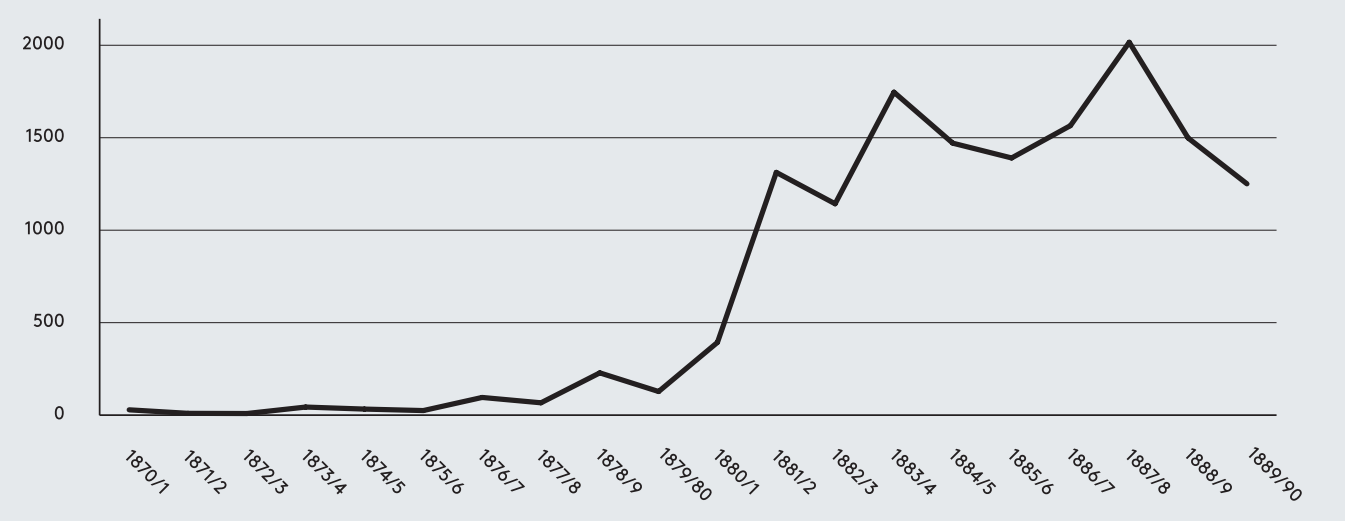

Figure 2: Graph showing the number of advertisements for Christmas cards appearing in the National Library's newspaper archive, Papers Past, between 1870 and 1890 . Its trajectory mirrors what we know from other sources about the Christmas card's rapid rise to 'craze' proportions in the early 1880 's, peaking around 1888 . Here, the Christmas card year is treated as occurring between March of one year and March of the next. This is to acknowledge the fact that, once typeset, adverts for booksellers were routinely repeated for some months after the New Year, regardless of aspects of those adverts being out of date. The figures relate to numbers of cards found in July 2017, and it should be noted that this graph is only intended to be indicative, as it may be distorted, owing to the number of digitised pages in the archive varying over time.

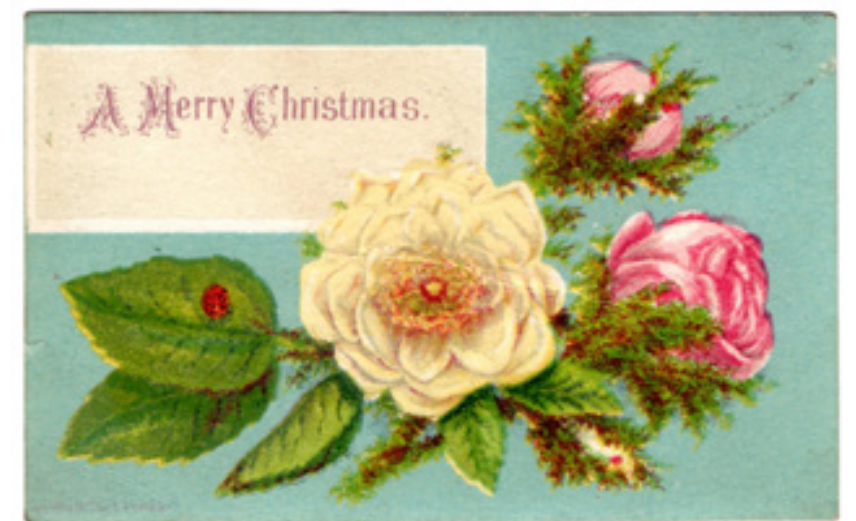

Yet, during the same decade, perhaps as many as 200,000 Britons had immigrated to New Zealand. ${ }^{20}$ This meant an influx of people imbued with contemporary British Christmas customs that increasingly included the newly-minted expectation of sending cards to absent friends and relations. With such a burgeoning potential market of migrants, all with overseas family and friends expecting to receive cards, it is not surprising that at some point, price notwithstanding, there would be a demand to send more Christmas cards 'home.' To accommodate such a demand, adverts would need to appear earlier, in time for the October Christmas post deadline. And, in 1880, adverts duly began to be placed during September, heralding an exponential increase in Christmas card advertising during 1880-2 (Figure 2).

This trend mirrors the pattern of the broader craze. Christmas card sending had, by 1879 , reached the point of being accepted as "a permanent and recognised institution." ${ }^{21}$ The following two years would see the Christmas card custom and trade become completely entrenched. ${ }^{22}$ Internationally, the business was burgeoning. As a measure of this, the New Zealand press reported on two major publishers, Louis Prang in Boston and Raphael Tuck in London, who, during 1880, held heavily publicised competitions for Christmas card designs and then aggressively marketed the winning cards as 'prize designs'. ${ }^{23}$ As a strategy, this worked. Prang and Tuck quickly became marketable brands, and the Lyttleton Times was the first to carry adverts where Prang's cards were specified by name. ${ }^{24}$ Prang is widely recognised as having popularised the Christmas card in America in $1875 .{ }^{25}$ The bulk of the company's early cards (Figure 3) featured the highly popular language of flowers - the Victorian equivalent of emojis. ${ }^{26}$ However, at least by 1879 , he was starting to link flowers to more nationally specific scenery (Figure 4 ). ${ }^{27}$ 


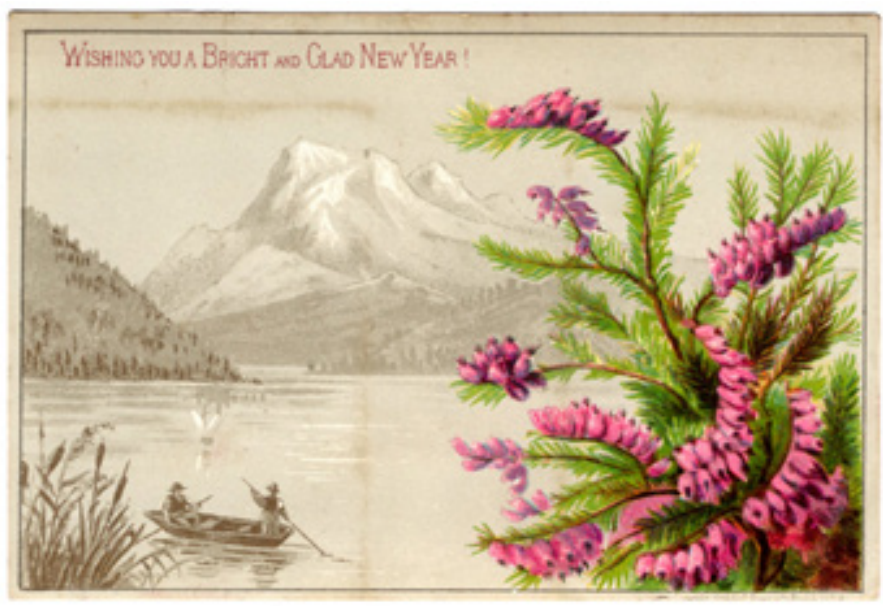

Both Prang's competition concept and the broader nationalistic impulse struck an Antipodean chord. In 1881, Sydney firm John Sands instituted a Christmas Card competition, whose rationale effectively defined the path New Zealand publishers would subsequently take. The Sydney Morning Herald reported it thus:

Up to the present time, the Christmas, New Year and Birthday Cards used in the colonies have been illuminated only by English or European subjects, this state of things arising from the want of sufficient enterprise among colonial manufacturers to offer any inducement by which more appropriate designs might be produced. The want was almost universally felt, as for an Australian born to gravely despatch to his friends and relatives a Christmas Card upon which were pretty pictures representing scenes of snow and ice, was an anomaly which must have struck every one. ${ }^{28}$

This argument clearly struck home in New Zealand where it was quoted in full in the press. ${ }^{29}$ But what constituted 'appropriate' designs? Culturally, the tendency was for Christmas customs to cohere around a single English imaginary conception which emphasised the British centre. ${ }^{30}$ Cards coming from Britain inevitably used imagery that reinforced this. The problem for New Zealand manufacturers was two-fold. To create cards that mimicked the British was to invite unfavourable comparison. But to try and re-imagine Christmas in a new environment was no easy task, especially when a large segment of the audience for such cards lived in Britain.
The popularity that saw the Christmas card become an institution made it a potentially attractive option for local publishers, but it also served to increase competition from well-resourced overseas competitors. As "Verges" in the Star pointed out, "Everyone has noticed the artistic excellence which is at present attained in the production of these little gifts of the season," and "the marvellous advance in the goods of this kind." Then followed a telling critique of the Australian offerings that had resulted from John Sands' competition:

Though, like most things in this vale of tears, they are not quite perfect, we may hail them as the dawning of a brighter day in Antipodean art. The figure drawing in most of them is very bad, but the native flowers and little landscapes will, in many instances, quite rival the productions of great London houses. ${ }^{31}$

Competing with major overseas producers on their own terms in offering seasonally specific imagery was risky. But while flowers and landscapes were already staples of the overseas genre, native flowers and Antipodean landscapes were subjects that gave European firms no great advantage. ${ }^{32}$ Unsurprisingly, therefore, these elements dominated early New Zealand attempts to enter the market.

The first of these occurred In September 1880, as New Zealand retailers for the first time targeted the international Christmas market. The Otago Witness reported that "we have received from Messrs J. Wilkie \& Co. some admirable specimens of Christmas cards, consisting of photographs of choice bits of New Zealand scenery, tastefully mounted, and forming elegant presents to send to friends outside the Colony." ${ }^{\prime 3}$ An advert in the Wanganui Herald tells us these were known as "Zealandia Christmas Cards" - a brand which Wilkie, as the agent for photographers the Burton Brothers, would continue to promote through the 1880 s. ${ }^{34}$

Wilkie was the only manufacturer to test the market in 1880 , but the following year saw tentative signs of an increase. At the niche end of the market, T. Rae was offering cards with mounted ferns as suitable for Christmas cards. ${ }^{35}$ In Wanganui, Mr P. Bell was reported as sending his customers "very pretty Christmas cards, enclosed in covers tastefully lithographed by Mr A.D. Willis, and which contain the almanac for 1882." ${ }^{136}$ Willis was no stranger to Christmas cards. As a bookseller he had first advertised with them almost a decade earlier. ${ }^{37}$ This, however, was his first tentative step towards printing them himself. Meanwhile Wilkie and the Burtons, in Dunedin, were again 
producing Zealandia cards, with the Evening Star reporting that they were "remarkable for unique treatment and fanciful designs. They make handsome pictures for scrap albums."

By 1882, the market for Christmas cards was intensifying. The Poverty Bay Herald, speaking from a consumer perspective, critiqued it thus:

This fashion, which was pretty enough in its commencement, is, however, likely at any time to be discredited by the spirit of vanity and competition which threatens to raise continually the money value of these trifles until they are no longer esteemed or sent unless purchased at a comparatively large price..$^{39}$

A consumer-led price-spiral was, on the other hand, catnip to the entrepreneur. 1882 proved to be the flashpoint for New Zealand cards. In Wanganui, A.D. Willis put out two lines of cards, reflecting the two most promising types mentioned earlier. One, a hand-painted series of cards of New Zealand flowers, ascribed to a "Wanganui lady," (probably Lydia Harding), was touted as removing "any necessity to import such mementos from Home for the purpose of sending them to friends at Home. ${ }^{\prime 40}$ Complementing these was a series of photographs of New Zealand scenery, mounted on cards printed with three-coloured depictions of ferns and nikau and captioned "A Merry Christmas and a Happy New Year." ${ }^{141}$ Some of the images were taken by Wanganui photographer, William James Harding, with others "procured from Dunedin." 42

Though Willis and Wanganui would later form the centre of Christmas card production, in 1882 Dunedin, with its reputation as a progressive centre of the arts and its thriving photographic industry, formed the locus of card activity. ${ }^{43}$ Unlike the expensive and complex chromolithographic printing techniques used by Willis and European Christmas card companies, photography was a more accessible and affordable entry-level medium. ${ }^{44}$ But the Otago cards shared one feature with Willis's offerings: cross-disciplinary collaboration. Though reproduced photographically, they were primarily assemblages of photographic and illustrative elements - an affront to later modernist sensibilities which perhaps accounts for their almost complete absence from discussions of any of the various photographers' oeuvre.

The Otago Christmas cards spanned a variety of subjects. One somewhat surprising Christmas offering was a pair of cartoons showing the retiring Dunedin mayor, James Gore, and the race for his successor,

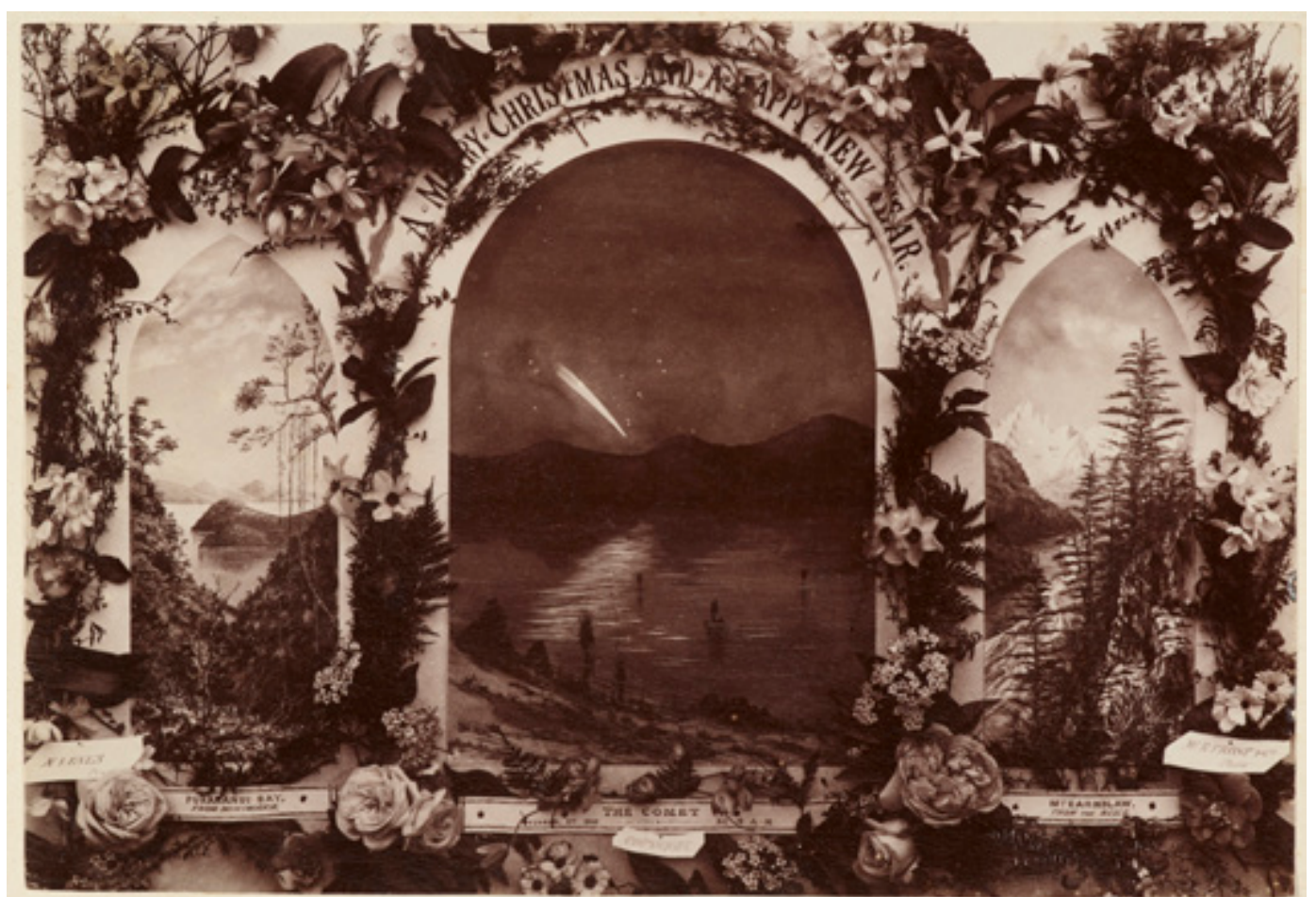

Figure 5: W. R. Frost (photography), Nathaniel Leves (artwork), Saunders, McBeath \& Co. (publishers), Comet Christmas Card, 1882, Albumen silver print, $194 \times 138 \mathrm{~mm}$. Courtesy of Te Papa. Copy purchased 1999 with New Zealand Lottery Grants Board Funds. Te Papa (O.021671). The Te Papa reference entitles it "A Merry Christmas and a Happy New Year."

both drawn by Arthur von Meyern and photographed and published by Robert Clifford. ${ }^{45}$ Here, photography was the mechanism of distribution, but the conception was illustrative. A more integrated approach was used by D.S. Jolly of Cromwell, who designed the floral border for his card, to complement photographs of Dunedin's Knox Church and its pastor taken by Dunedin photographer Frank A. Coxhead. ${ }^{46}$

Coxhead was also the photographer for a card by Nathaniel Leves, which was heavily promoted at the Benevolent Institute's 1882 Carnival. ${ }^{47}$ It included a 'Christmas anthem' with words by John Barr and music by the organist of Knox Church, A.J. Barth. ${ }^{48}$ This is probably the same card described elsewhere as follows: "The music and words of "Our New Zealand Christmas Song" has been beautifully photographed, cabinet size, with a pretty view of Otago Harbor, encircled with ears of corn and flowers. ${ }^{\prime 49} \mathrm{~A}$ report on the carnival mentioned Leves' offerings as including "an assortment of his photographic Christmas cards." This implies multiple cards, but only one other design received press 
attention - his collaboration with photographer W.R. Frost, also an exhibitor at the Carnival. Indeed, by the time they were exhibiting their card was already a cultural phenomenon, receiving national attention as 'the Comet Christmas Card,' (Figure 5).

The 1882 comet had been visible from September. This timing meant that it was not possible for northern hemisphere publishers to produce and export cards of it back to New Zealand. ${ }^{51}$ Local producers, of whom Leves was the first, must have known that this made it ideal subject matter for Christmas cards, whether sent overseas or not, and Leves sounded a familiar note in justifying the card. As the Evening Star reported:

Mr Leves was struck with the absurdity of New Zealand residents sending to friends at Home cards which had in the first place come from there, and which were typical of a Home Christmas; he therefore set to work to produce a card which should be representative of Christmas in New Zealand, and has obtained a very happy result. ${ }^{52}$

This intent was spelt out by the verse on the reverse of the mount, which provided captions for the scenes and said, in part:

Summer scenes and flowers are ours at Christmas time, Not wint'ry frost and snow, as yours in Northern Clime.

But still our hearts commingle, and kindly thoughts arise,

Recalling distant lov'd ones who dwell 'neath other skies. ${ }^{53}$

The Star noted that the card was sold for a shilling (the normal price for such cards), and the firm Saunders McBeath had the rights to sell it. ${ }^{54}$ Although the cards appears photographic, night photography was not, at this period, viable. ${ }^{55}$ The artwork was actually skilful black and white painting by Leves showing the comet over the Otago Peninsula Hills, with flanking scenes of other Otago beauty spots, Purakanui Bay and Mount Earnslaw. ${ }^{56}$ In format, the triptych is similar to the Cole/Horsley card (Figure 1), but here the resemblance ceases. It does not try to narrate Christmas as a social experience, or show different ways of celebrating Christmas in the summer. Rather, the three scenes serve to advocate for the new colony, portraying New Zealand as an enviable destination - the idyllic Britain of the South. ${ }^{57}$ The design highlighted the Romantic aspects of the New Zealand landscape, foregrounded the novelty of the comet, and topped it off with the mix of local and imported flowers and plants that might decorate Christmas celebrations during a New Zealand summer. At least two different versions of the card exist, with different types of flower on each. ${ }^{58}$ The design was widely celebrated. Gisborne's Poverty Bay Herald was particularly enthusiastic, saying "scarcely anything more acceptable to Home acquaintances could be imagined," before praising Leves" "charming sketches" and noting that "the views are set in an embroidery of flowers and ferns, in the design of which much taste has been displayed." ${ }^{59}$

The card may have been a triumph of design, but the countrywide acclaim testified to a triumph of marketing. No other card to date had been sold so widely, with Saunders McBeath \& Co. mustering a network of agents and licensees. For example, Wanganui draper Joseph Paul, in direct competition with Willis, was offering 1000 cards, while newspaper adverts show it also on sale in Invercargill, Milton,

Riverton, Christchurch, Hawera and New Plymouth. ${ }^{60}$ Auckland retailer W. Rattray was a particularly active agent, advertising the card in Gisborne, Thames and Hamilton. ${ }^{61}$ Many of the retailers involved were drapers and fancy goods sellers, and thus reflected a current trend whereby a range of merchants began muscling in on booksellers' traditional territory by offering Christmas cards. ${ }^{62}$

The adverts nevertheless share a complete confusion around authorship. Most only credited the retailer, whilst those that went further named Saunders McBeath, not Leves, despite the Evening Star piece stating that Saunders McBeath had purchased the right to sell them. ${ }^{63}$ But the agents' name was on the back of the card, which is why Alison Clarke also credited them, not Leves, as the author. ${ }^{64}$ Greetings card artists were routinely anonymous, with publishers rather than artists normally being credited, so this may account for the lack of consistency. ${ }^{65}$ Nor is this situation helped by the photographic firm of W.R. Frost \& Co. subsequently claiming to be "Publishers of the Original Comet Christmas Card."bo

The same lack of clarity appears in the relationship between the Burton Brothers and Wilkie, who were once again publishing scenic "Zealandia Christmas Cards." 67 Their respective roles as photographer and agent were, however, spelt out on the central panel of their Comet card, (Figure 6) and both names appeared on the reverse where, despite the card not having a Burton Brothers number, that company figured more prominently (Figure 7). ${ }^{68}$

Regardless of ultimate authorship, neither Wilkie nor the Burtons can have been thrilled when Leves beat them to comet glory by a mere three days. Their Five Comet Card (Figure 6) had a central image 
of the comet over Dunedin's Knox Church, which was situated both historically and geographically by the flanking images. Photographs by the Burtons of four iconic South Island scenes (Mount Cook, Mitre Peak, Milford Sound and Lake Wakatipu), were interspersed with drawings of four historical comet appearances. Like Leves' offering, this card received a positive press response, with the Otago Daily Times noting that it had "a scientific and historical value as well as a local interest" and that it was a "charming and characteristic card." ${ }^{69}$ However, it was only advertised in the Otago region, and although its scenes were of better known New Zealand tourist landmarks than the more local scenes drawn by Leves, it was Leves' card that proved more marketable. Though both advertised the beauties of Britain of the South, a sumptuous and well-constructed design, giving greater prominence to the local scenery evidently appealed more to Christmas sensibilities than the more fragmented mix of comets and scenes.

Nevertheless, the similarities between the two cards are significant. Both combine landscape and foliage. Both combine native plants and imported flowers. Both cater to English and Scots sensibilities by mentioning both Christmas and New Year. Both were either created as series, or ran to more than one edition, with different versions characterised by differing floral treatments. ${ }^{70}$ Both have a mix of illustrative and photographic elements that are then reproduced photographically. Both eschew the easier route of simply showing a single New Zealand scene with a Christmas message, instead opting for a composite, montaged, multiview treatment with floral borders. The overall effect was lavish. The Burtons' card, in particular, visually mimics the layout of an album page and, in its construction, can be seen as analogous to the way periodicals applied the 'frame story. ${ }^{17}$ Although a well-established print format by 1882 , the multiview would retain a link with Christmas well into the twentieth century, suggesting that these cards were either applying a pre-existing Christmas visual trope, or that they themselves may have exerted a real influence on later visual formulations of the season. ${ }^{72}$

At all events, both cards connected the comet experience with imagery that aimed to convey a Southern Hemisphere Christmas, and they shared the desire to communicate this difference with people overseas. But, while the Leves and Burton cards were the most prominent comet cards, they were not the only ones. The most novel Dunedin card, showing the comet, a lighthouse and an eclipse, was produced by Fermor Willson and was luminous - for viewing in the dark. ${ }^{73}$ Willson was likely using this to promote a new "Balmain's"
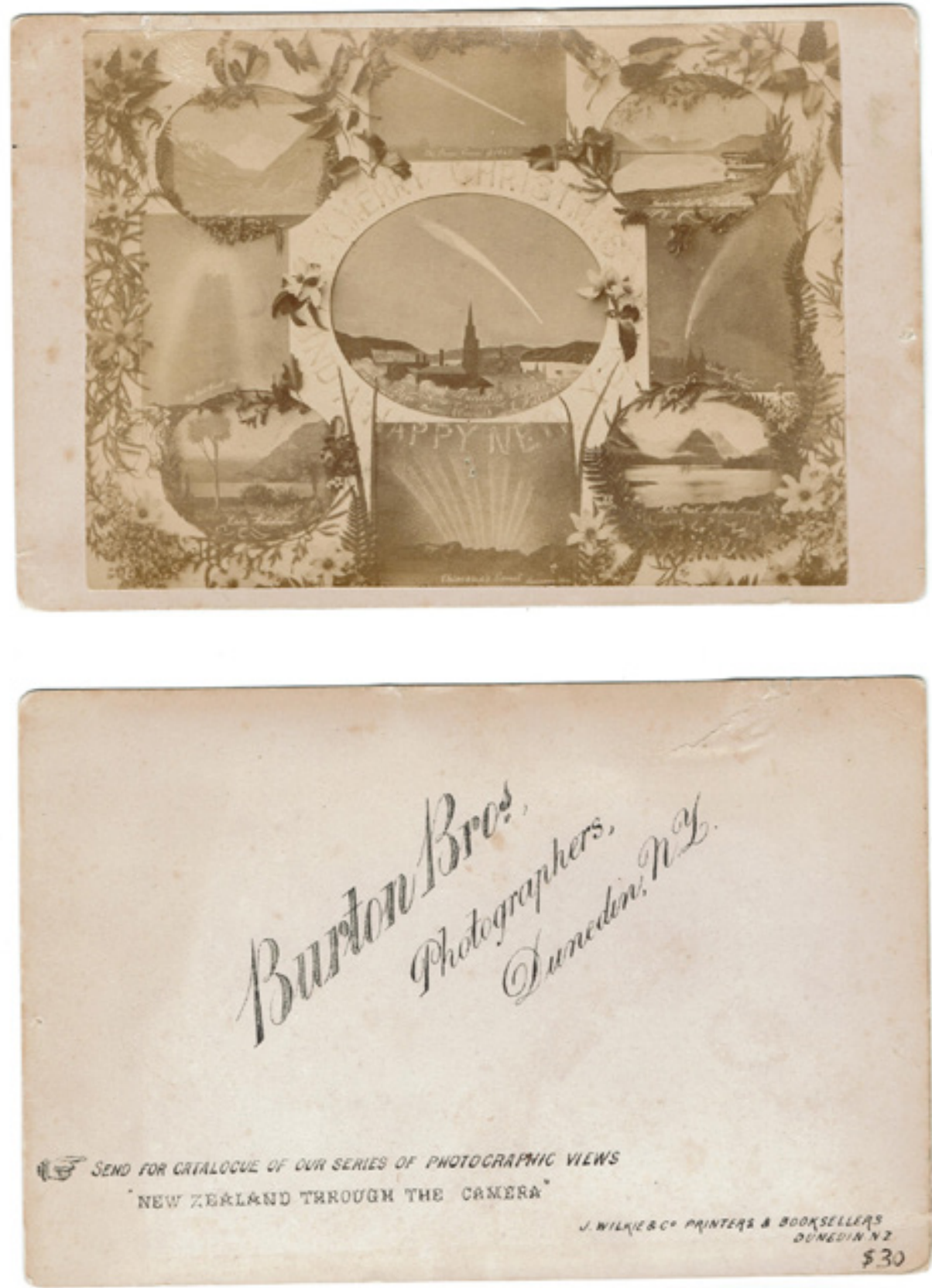

Figure 6 (top): Burton Brothers (photography), J. Wikie \& Co. (Agents), Five Comets Christmas Card, 1882 , Albumen print (?), $137 \times 101 \mathrm{~mm}$. Courtesy of the collection of Jenny Long.
Figure 7 (bottom): Reverse of Figure 6, showing the Burton Brothers and Wilkie credits and suggesting that the Burton Brothers were the primary mover in creating the card. Card, $164 \times 108 \mathrm{~mm}$. Courtesy of the collection of Jenny Long. 
luminous paint, which he had started to stock earlier in the year. ${ }^{74}$ Other photographers created comet cards in both Auckland and Wellington. Wellington's William Brickell Gibbs published two..$^{75}$ Their success is arguable, since by mid-December a Lambton quay jeweller was offering his own card, consisting of a photograph of the comet over the Wellington Hills taken by Gibbs - suggesting that Gibb may have offloaded surplus stock. ${ }^{76}$ In Auckland, a single advert speaks of a "Comet Christmas card with views of Auckland and [the] North Shore." ${ }^{17}$ Nevertheless, until examples of these cards are located, it is hard to know how they negotiated the balance of seasonal and local elements.

Only one 1882 card appears to have bucked the trend and envisaged the variety of colonial Christmases. This card has similarly murky authorship issues, but was published by Dunedin drapers Mollison, Duthie and Co., with artwork by George F. Fodor and photography by the Burton Brothers. ${ }^{78}$ It was described in detail by the Bruce Herald:

The centre of the card contains a pair of clasped hands with the mottoes, "Hands all round" and "Should auld acquaintance be forgot." Above is a view of a street in Egypt. On the left, Christmas in Australia, with a couple of wild bushmen on horseback shaking hands. To the right, Christmas in New Zealand, represented by some tents, several rough characters jollifying around, with a tin billy occupying the place of honor in the foreground. Below is Christmas in Old England, with its festive gathering, social board, and Christmas tree. ${ }^{79}$

The November publication date shows that this card was aimed at the New Zealand market, so its somewhat caricatured contrast of the outdoor colonial Christmas with the nostalgic depiction of Old English celebration is particularly telling. It was normal, in Christmas periodicals, to frame the colonial Christmas as an Arcadian outback feast. ${ }^{80}$ Yet, though the format of this card potentially connotes a fractured identity, its colonial focus and normative English scene ultimately locate Christmas within the broader unifying framework of 'Greater Britain', a concept that was itself a response to the changing base of Britishness. ${ }^{81}$ For individuals, however, the heavy emotional toll involved in negotiating this territory is well articulated by the Bruce Herald' writer who, prior to describing the "pretty" card, had noted that "we thank [Mollison, Duthie \& Co.] for the card, but are not thankful to them for suggesting reminiscences which have brought on the 'winter of our discontent' in this country." The piece concludes by saying:

Christmas in the colonies always stir[s] up in our mind a host of recollections which, though pleasing in themselves, are exquisitely painful by contrast, and Messrs Mollison, Duthie, $\&$ Co. have been good enough to bring on that feeling of wretchedness which visits us every year more than a month before the time. It is not kind of them. The only way in which a British born subject can enjoy a merry Christmas in this "new world of ours" is by forgetting all about Christmas in the old world, and that he can hardly do without getting outside of enough whisky to produce mental oblivion. ${ }^{82}$

By the 1880's, and despite continuing immigration, increasing numbers of New Zealanders were not British born, providing a tension between those for whom a summer Christmas was normal, and those for whom it was an aberration. Had Mollison, Duthie \& Co., as a local firm, opted to show only a New Zealand and an English Christmas, they might have highlighted this fractured New Zealand experience. Instead, by adopting a multiview format to show a variety of traditions pivoting around core English practices, they ultimately created an image that exemplifies the colonial ideal.

For Greater Britain, with its assertion of the British cultura continuity across the colonies, to be a reality, common forms of celebration were necessary. Christmas had to be both embedded and maintained. The English Christmas card's post-1860s' focus on imagery of the seasons complicated the process of establishing a common colonial Christmas vocabulary. Imported cards, with their winter scenes, appealed because they spoke to immigrants' memories and their enduring sense of the proper way to celebrate a distinctly English holiday. New Zealand card producers, however, regarded the Christmas card as a venue to foreground New Zealand's distinctive summertime celebration, allowing locals to advertise the country's charms and differences to their friends. Of the fourteen $1882 \mathrm{New}$ Zealandproduced cards (or card series) identified here, the majority opted to frame a New Zealand Christmas by using flowers and landscapes. But such subject matter was standard for cards around the world, and consequently the local cards maintained enough similarity to avoid fully transgressing recipients' expectations. In other words, the specific content provided a flavour that allowed New Zealanders to differentiate 
without disassociating. This aligns with Mark Connelly's conclusion that the colonial Christmas was typified by a "co-existence of themes and traditions" that allowed a "nascent sense of nationhood" while bolstering a broader sense of Britishness. ${ }^{83}$ Despite this, although the marketing rhetoric of the Christmas card entrepreneurs appears to fit with a narrative of emerging nationalism, their choice of visual rhetoric closely follows Peter Gibbons' prescription of what cultural colonisation might look like. ${ }^{84}$ Circulating carefully labelled images of native flora and unspoilt, iconic natural landscapes was a method of establishing possession, one that integrated settler experience within the broader colonial framework. It was no coincidence that the signifiers chosen were drawn from New Zealand's nature rather than its culture. ${ }^{85}$ Māori as well as Pākehā celebrated Christmas. ${ }^{86}$ Yet they did not figure in any of the cards' imagery, and could rightfully have been a little cynical about a debate that excluded them while pitting one form of cultura colonisation against another.

Ultimately, the fact that the local Christmas card industry quickly gained momentum between 1880-82 shows that a sizeable group of pākehā New Zealanders wanted to support local enterprise and responded to narratives that asserted the distinctiveness of their Christmas experience. This was why, from 1883, A.D. Willis trumpeted the message of supporting local industry as he advertised his fully chromolithographic coloured Christmas cards of New Zealand landscapes. ${ }^{87}$ But, for all his nationalist fervour, he was not able to compete with the flood of imported cards. ${ }^{88}$ Within a Greater British framework, there was intrinsically no reason for colonists to avoid sending back images of an Old English Christmas, since the imagery on imported cards would remain meaningful to recipients in Britain, as well as reinforcing a shared cultural reference point if sent locally. By exploring the ways designers and manufacturers adapted the Christmas card craze to New Zealand, this paper has shown that despite the attempt to localise, they were unable to escape the broader apparatus of colonialism. Tempting as it is to frame the development of New Zealand Christmas card as an example of embryonic nationbuilding, the narrative is better interpreted as a smaller chapter in a different yuletide story - one bearing an indelibly imperial stamp.

\section{REFERENCES}

Belich, James. Making Peoples: A History of the New Zealanders from Polynesian Settlement to the End of the Nineteenth Century. Auckland: Penguin, 1996.

Bell, Duncan. The Idea of Greater Britain: Empire and the Future of World Order, 1860-1900. Princeton: Princeton University Press, 2007.

Blair, Arthur. Christmas Cards for the Collector. London: B.T. Batsford, 1986.

Buday, George. The History of the Christmas Card. London: Spring, 1954.

Clarke, Alison. Holiday Seasons: Christmas, New Year and Easter in Nineteenth-Century New Zealand. Auckland, New Zealand: Auckland Univer-

sity Press, 2007

Cocker, Alan. "Photographers Hart, Campbell and Company: The Role of Photography in Exploration and National Promotion in Nineteenth Century New Zealand." Backstory, no. 2 (2017): 93-105

Connelly, Mark. Christmas: A History. Paperback ed. London: I.B. Tauris, 2012.

Ell, Sarah. A New Zealand Christmas: Three Centuries of Kiwi Christmas Celebrations from the Alexander Turnbull Library. Auckland, NZ: Godwit, 2008.

Ettlinger, L. D., and R. G. Holloway. Compliments of the Season. London: Penguin, 1947.

Gibbons, Peter. "Cultural Colonisation and National Identity." New Zealand Journal of History 36, no. 1 (2002): 5-17.

Gilderdale, Peter. "Hands across the Sea: Situating an Edwardian Greetings Postcard Practice." PhD, Auckland University of Technology, 2013.

Hancox, Barry. "Southern Hemisphere Christmas Greetings Cards - Part Two." NZ Ephemerist, no. 2 (2009): 23-29.

---. "Southern Hemisphere Christmas Greeting Cards: Part One." NZ Ephemerist, no. 1 (2008) 14-18.

Hutton, Ronald. The Stations of the Sun: A History of the Ritual Year in Britain. Oxford: Oxford University Press, 1996.

Jackson, Alan. New Zealand Postcards: Rates
\& Regulations to 1939. Auckland: Postal History Society of New Zealand, 1984.

Johnston, Rosslyn Joan. "Colour Printing in the Uttermost Part of the Sea: A Study of the Colour Print Products, Printers, Technology and Markets in in New Zealand, 1830-1914." Doctoral Thesis, Vic-
toria University of Wellington, New Zealand, 2002. Knight, Hardwicke. Burton Brothers: Photographers. Dunedin: John Mclndoe, 1980.

Maddock, Shirley, and Michael Easther. A Christmas Garland. Auckland: Collins, 1980.

Nissenbaum, Stephen. The Battle for Christmas. New York: Alfred A. Knopf, 1997.

Phillips, Jock, and Terry Hearn. Settlers: New Zealand Immigrants from England, Ireland and Scotland 1800-1945. Auckland: Auckland University Press, 2008

Piesse, Jude. British Settler Emigration in Print, 1832-1877. Oxford: Oxford University Press, 2016.

Restad, Penne L. Christmas in America: A History. Oxford: Oxford University Press, 1995.

Robertson, G. I. "The Christmas Card: Its Origin and Early Use in New Zealand." The Mail Coach 51, no. 1 (2014): 12-18.

Storey, John. Inventing Popular Culture: From Folklore to Globalization. Malden, MA: Blackwell, 2003.

Tuato'o Ross, Cathy. "'Water Babies in Maoriland': Photomontage in the Illustrated Press." In Early New Zealand Photography: Images and Essays, edited by Angela Wanhalla and Erika Wolf, 139-44. Dunedin: Otago University Press, 2011.

White, Gleeson. Christmas Cards and Their Chief Designers. London: Studio, 1895.

Whybrew, Christine. "The Burton Brothers Studio Commerce in Photography and the Marketing of New Zealand, 1866-1898." Doctoral Thesis, University of Otago, 2010.

---. "Text and Image in Alfred Burton's Photograph of the Scene of the 'Hursthouse Outrage' at Te Kumi (1885)." In Early New Zealand Photography: Images and Essays, edited by Angela Wanhalla and Erika Wolf, 60-65. Dunedin: Otago University Press, 2011. 


\section{ENDNOTES}

1 Evening Star, "Christmas Cards," 5 October 1883, p.2, quoting Burton Brothers promotional material.

2 Two authors have examined the history of NZ Christmas cards in an introductory sense, though neither in academic venues. G. I. Robertson documented some of the primary sources for a study of the Christmas card, G. I. Robertson, "The Christmas Card: Its Origin and Early Use in New Zealand," The Mail Coach 51, no. 1 (2014). Barry Hancox published two papers on the subject of chromolithographic and photographic New Zealand Christmas Cards, and their broader context, Barry Hancox, "Southern Hemisphere Christmas Greetings Cards: Part One," NZ Ephemerist, no. 1 (2008).; "Southern Hemisphere Christmas Greetings Cards - Part Two," NZ Ephemerist, no. 2 (2009). Rosslyn Johnson also covered aspects of the early trade in her study of A.D. Willis's cards, Rosslyn Joan Johnston, "Colour Printing in the Uttermost Part of the Sea: A Study of the Colour Print Products, Printers, Technology and Markets in New Zealand, 1830-1914" (Doctoral Thesis, Victoria University of Wellington, New Zealand, 2002), 311-20.

3 Jude Piesse, British Settler Emigration in Print, 1832-1877 (Oxford: Oxford University Press, 2016), 54. In particular Piesse focuses on the role played by popular periodicals in absorbing and containing the threat to British identity posed by colonisation.

4 Alison Clarke, Holiday Seasons: Christmas, New Year and Easter in Nineteenth-Century New Zealand (Auckland, New Zealand: Auckland University Press, 2007), 1-2, 23, 34, 40-41. Other works on the NZ Christmas include Shirley Maddock and Michael Easther, $A$ Christmas Garland (Auckland: Collins, 1980). and Sarah Ell, A New Zealand Christmas: Three Centuries of Kiwi Christmas Celebrations from the Alexander Turnbull Library (Auckland, NZ: Godwit, 2008).

5 Peter Gibbons, "Cultural Colonisation and National Identity," New Zealand Journal of History 36, no. 1 (2002): 7-8.

6 Clarke, 46.

7 John Storey, Inventing Popular Culture: From Folklore to Globalization (Malden, MA: Blackwell, 2003), 17.
8 Stephen Nissenbaum, The Battle for Christmas (New York: Alfred A. Knopf, 1997), 6. Ronald Hutton, The Stations of the Sun: A History of the Ritual Year in Britain (Oxford: Oxford University Press, 1996), 112-14, 21, 487. Mark Connelly contests the widespread belief that the Victorians reinvented Christmas, saying that they reshaped it in the spirit of antiquarian protection. Mark Connelly, Christmas: A History, Paperback ed. (London: Christmas. A History, Paperback ed. (London: I.B. Tauris, 2012), 2-3. It is worth noting, as an antidote to the academic consensus that Christmas was not a religious holiday, that Christmas card collector Arthur Blair found numerous examples of early cards with religious subject matter. Arthur Blair, Christmas Cards for the Collector (London: B.T. Batsford, 1986), 30.

9 On the nature of Christmas in the periodical press, see Piesse, 49-80.

10 On earlier Religious Tract Christmas cards, see Robertson, 13. On other forerunners to the Christmas card, see George Buday, The History of the Christmas Card (London: Spring, 1954). Although old, Buday's book remains the most comprehensive piece of original research on the history of the Christmas card.

11 The Otago Daily Times, "News from Home," 23 January 1875, p.6. This quote gives a New Zealand perspective on typical British Christmas card imagery, remarking on "time honoured representations of robins perched on snow-laden trees." Buday also sees robin as the dominant motif of the period. 100. whilst Ettlinger and Holloway focus more generally on winter scenes. L. D. Ettlinger and R. G. Holloway, Compliments of the Season (London: Penguin, 1947), 25.

12 New Zealander, "Christmas Gifts," 21 December 1861, p.3. Buday gave 1862 as the date for the first serious commercial Christmas card publishing, but this advertising suggest we should put the date at least a year earlier. Buday, 100. This 1861 reference pred Buday, 100 . This 861 reference predates the earliest mention found by Robertson by a year. Robertson, 13

13 New Zealand Herald, "Spectemur Agendo," 13 December 1876, p.2. Mark Connelly uses an 1881 quote from the Lady's Pictorial to show Christmas card display as being the indicto of the impending season. Connelly, 192.
14 Clarke, 15, 37

15 Otago Daily Times [untitled], 21 October 1876 p.2. On Scottish unfamiliarity with Christmas, see Clarke, ibid., 37

16 Connelly, 189

17 Buday, 53.

18 Alan Jackson, New Zealand Postcards: Rates \& Regulations to 1939 (Auckland: Postal History Society of New Zealand, 1984), 2. This was evidently not known to all. As late as 1881 , papers were belatedly advising readers that they could send cards half price nationally (at "book rates") for a penny, if the envelope was left open. Thames Advertiser, [untitled], 29 December 1881, p.3.

19 A list of postal rates that applied during this period can be found in the New Zealand Herald, "Postal Rates, \&c.," 1 January 1883, [supplement]. Letters within New Zealand and Australia were $2 d$, whilst it cost $6 d$ to send a letter to the rest of the world.

20 Jock Phillips and Terry Hearn, Settlers: New Zealand Immigrants from England, Ireland and Scotland 1800-1945 (Auckland: Auckland University Press, 2008), 41.

21 The Globe, [untitled], 26 April 1879, p.2.

22 Buday, 57-8.

23 E.g. Lyttleton Times, "Literary and Art Notes," 18 January 1881, p.5; Otago Daily Times, "Advertisements," 26 December 1881, p.1. On Raphael Tuck's competition see Peter Gilderdale, "Hands across the Sea: Situating an Edwardian Greetings Postcard Practice" (PhD, Auckland University of Technology, 2013), 225-6. On Prang's competition, see Penne L. Restad, Christmas in America: A History (Oxford: Oxford University Press, 1995), 121-2.

24 Timaru Herald, "Christmas at Home," 20 October 1880, p.1.

25 Restad, 118.

26 On the language of flowers, see Gilderdale, 180-3, 434-8.

27 Although Restad notes that Prang's cards catered to American taste, there is no evidence that nationalism was a driver of the competition itself, which was framed around issues of making good art more available for the masses. Restad, 120-22. Nevertheless, cards like figure 4 were arriving in the $\mathrm{New}$ Zealand market.
28 Sydney Daily Telegraph, “Mr. John Sands' Fine Art Competition," 28 May 1881, p.3.

29 Bay of Plenty Times, "Fine Art Competition in Sydney," 16 June 1881, p.2. (N.B. this Papers Past item is only locatable under the misspelling 'competiton'); Ashburton Guardian, "Our Sydney Letter," 11 June 1881, p.2.

30 Piesse, 57.

31 Star, "Random Gossip," 29 December 1881, p.3. The author misattributes the Australian competition cards to another early entrant into the Australian market, Gibbs, Harland and Co.

32 Roslyn Johnston makes this point in relation to A.D. Willis's cards: Johnston, 315.

33 Otago Witness, "News of the Week," 18 September 1880, p.18.

34 Wanganui Herald, "Advertisements," 8 December 1880, p.2. Christine Whybrew's extensive PhD thesis on the Burton Brothers' work does not address their Christmas card production in any detail, perhaps because the negatives have not survived. Christine Whybrew, "The Burton Brothers Studio: Commerce in Photography and the Marketing of New Zealand, 1866-1898" (Doctoral Thesis, University of 0 University of Otago, 2010). They nevertheles fit well into her overall argument that the Burton's work needs to be understood within an international culture, where images were commercial products that were mediated by accompanying texts.

35 Evening Post, "Advertisements," 15 October 1881, p.3.

36 Wanganui Chronicle, "Local and General," 26 December 1881, p.1.

37 Wanganui Herald, "Advertisements," 19 October 1872, p.3. 1872 was Willis's first year in trade as a bookseller. Johnston, 292.

38 Evening Star, [untitled], 5 December 1881, p.2

39 Poverty Bay Herald, "Small Courtesies," 18 November 1882, p.5.

40 Wanganui Herald, "The Taupo Road," 21 November 1882, p.2. Robert Coupland Harding noted his cousin Lydia had done flower paintings for later Willis cards. Johnston, 317. As yet, I have not been able to positively identify any of this series of cards in museum collections.

41 Wanganui Herald, [untitled], 16 October 
1882, p.2. The card of the previous year was lithographed. It is unclear whether the three colour printing here is an early introduction of chromolithography on Willis's part. It is generally thought that Willis did not introduce the technique until 1883. Ibid., 302.

42 Ibid. The Herald did not mention Harding by name, while the Wanganui Chronicle's reportage on the same day mentioned Harding, but not Willis. Wanganui Chronicle, "Local and General," 16 October 1882, p.2. Willis's involvement with the Herald probably accounts for this.

43 On Dunedin's photographic trade, see Whybrew, 27.

44 Hancox, "Southern Hemisphere Christmas Greetings Cards - Part Two," 23.

45 Evening Star, [untitled], 22 December 1882 p.2; Otago Daily Times, [untitled], 23 December 1882 , p.2.

46 Evening Star, [untitled], 24 November 1882, p.2.

47 Leves' art has been largely overlooked in New Zealand, where he is noted as a glass embosser and photographer https://teara. govt.nz/en/biographies/2f24/fraser-robert-henry; http://canterburyphotography. blogspot.co.nz/2009/03/leves.html?m=0. However, in 1876 he was advertising that he had thirteen years' experience in London as a house decorator, Otago Daily Times, "Advertisements," 28 August 1876, p.5. For the Carnival, he labelled himself a signwriter and decorator, Evening Star, "Advertisements," 31 October 1882, p.3. This is the same occupation listed in the probate notice when he died in Australia. Melbourne Argus, "Advertising" 27 March, 1890, p.10. On the 1882 Carnival itsel see Otago Benevolent Institution, [1882], "Twentieth Annual Report of the Committe of Management of the Benevolent Institution," p.43, in the Pamphlet Collection of Sir Robert Stout, Vol 49, http://nzetc.victoria. ac.nz/tm/scholarly/tei-Stout49-t21-body-d11. html

48 Evening Star, [untitled], 22 November 1882, p.2.

49 Ashburton Guardian, [untitled], 21 November 1882 , p.2.

50 Otago Daily Times, "The Carnival," 27 November 1882, p.2.
51 Gilderdale, 234.

64 Clarke, 44

Evening Star, [untitled], 14 October 1882, p.4. Given that the view of the comet is dated October 8th, the time between creation and publication was very short.

53 The Auckland Star published the full poem Auckland Star, [untitled], 4 November 1882 , p.2. This text is also quoted by Alison Clarke, Clarke, 44.

54 Evening Star, [untitled], 14 October 1882, p.4.

55 Alan Cocker cites an 1881 source on the impossibility of night photography, Alan Cocker, "Photographers Hart, Campbell and Company: The Role of Photography in Exploration and National Promotion in Nineteenth Century New Zealand," Backstory, no. 2 (2017): 97.

56 The modern spelling is Purakaunui, but the card uses the normal nineteenth century spelling.

57 James Belich, Making Peoples: A History of the New Zealanders from Polynesian Settlement to the End of the Nineteenth Century (Auckland: Penguin, 1996), 282, 302-3.

58 The other version, from the Otago Settlers Museum, is reproduced in Clarke, 44.

59 Poverty Bay Herald, [untitled], 24 October 1882, p.2. The Herald's piece amplifies the views of the Otago Daily Times, [untitled], 14 October 1882, p.2, where they also talk about a tasteful "embroidery of flowers and ferns."

60 Southland Times, [untitled], 17 October 1882 p.2; Bruce Herald [untitled], 20 October 1882 , p.3; Western Star, [untitled], 25 October 1882, p.2; Lyttleton Times, "Advertisements," 3 November 1882, p.4; Taranaki Herald, "Advertisements," 22 November 1882, p.3.

61 Poverty Bay Herald, [untitled], 24 October 1882, p.2; Thames Advertiser, [untitled], 7 November 1882, p.2; Waikato Times, "Notices," 7 November 1882, p.2.

62 Gleeson White noted this trend, blaming drapers for the introduction of cheap cards. Gleeson White, Christmas Cards and Their Chief Designers (London: Studio, 1895), 44 Mark Connelly's quote from the 1881 Lady's Pictorial (cited above in note 13), mentions the market expanding to Drapers, Milliners and Toy Sellers, away from its "legitimate" setting of the bookseller. Connelly, 192.
65 Gilderdale, 227-30.

66 Evening Star, "Late Advertisements," 7 November 1882, p.2.

67 North Otago Times, [untitled], 18 October 1882 , p.2. The paper credits the cards to Wilkie, and comments that they received "selection of" the cards, thus showing that there were multiple designs created. Christine Whybrew notes that the Burton Brothers were themselves a group of photographers operating under a single label, so authorship is thus further clouded. Christine Whybrew, "Text and Image in Alfred Burton's Photograph of the Scene of the 'Hursthouse Outrage' at Te Kumi (1885)," in Early New Zealand Photography: Images and Essays, ed. Angela Wanhalla and Erika Wolf (Dunedin: Otago University Press, 2011), 62-4.

68 On the company's use of numbers see Whybrew, ibid., 62. It is worth noting that some other composite images like their "Great Composite" appear to be unnumbered. Hardwicke Knight, Burton Brothers: Photographers (Dunedin: John McIndoe, 1980), 17.

69 Otago Daily Times, [untitled], 21 October 1882, p.2. The card was first advertised on the 17th. Evening Star, [untitled], 17 October 1882, p.2.

70 The image in Barry Hancox's collection differs from that reproduced here. See Hancox, "Southern Hemisphere Christmas Greetings Cards - Part Two," 28. The fact that both

Leves' and the Burtons' cards have more than one version makes it more likely that this was a marketing ploy, rather than a result of the glass plates both requiring reshooting after damage - though this remains a possible explanation, as does their being reshot at a later time.

71 On the analogy with album pages see Gilderdale, 251. On the frame story see Piesse, 58-9.

72 Cathy Tuoto'o Ross notes that what she terms a photomontaged form was most prominen in Christmas numbers of the periodical press. Cathy Tuato'o Ross, "Water Babies in Maoriland': Photomontage in the Illustrated Press," in Early New Zealand Photography: Images and Essays, ed. Angela Wanhalla and Erika Wolf (Dunedin: Otago University Press, 2011), 139-40.

73 Evening Star, [untitled], 13 November 1882 p.2.

74 Otago Witness, "News of the Week," 11 March 1882, p.9.

75 Evening Post, [untitled], 18 November 1882, p.2.

76 Evening Post, [untitled], 12 December 1882 p.2; Marlborough Express, "Local and General News," 16 December 1882, p.2.

77 Auckland Star, "Wanted," 13 November 1882 p.3.

78 Evening Star, [untitled], 13 November 1882 p.2

79 Bruce Herald, [untitled], 21 November 1882, p.3.

80 Piesse, 75-7. On the Arcadian concept in New Zealand, see Belich, 304-5.

81 Duncan Bell, The Idea of Greater Britain: Empire and the Future of World Order, 18601900 (Princeton: Princeton University Press, 2007), 33-4. Jude Piesse notes the way that Christmas periodicals created an international sense of Christmas synchronicity centred round the English hearthside experience. Piesse, 54.

82 Bruce Herald, [untitled], 21 November 1882, p.3. The comment about whisky may be ironic, given that the preceding editorial section, pp.2-3, was about the dangers of the colonial drinking culture.

83 Connelly, 108, 31-2. See also Piesse, 80.

84 Gibbons, 10-11.

85 Ibid.

86 Clarke, 26-30.

87 Willis's card production from 1883 and through the rest of the decade is so extensive as to warrant separate study. This has been begun by Rosslyn Johnston, Johnston, 311-20. 88 Gilderdale, 232-4, 468-70. 